\title{
COVID-19 and Dermatologist: A Scenario from Nepal
}

\author{
Deeptara Pathak Thapa', Vikash Paudel ${ }^{2}$
}

${ }^{1}$ Nepal Medical College, Kathmandu, Nepal; ${ }^{2}$ National Medical College, Parsa, Nepal

\begin{abstract}
Corona virus disease-2019 (COVID-19) had impacted the healthcare sector severely. The impact of pandemic had a foothold even on dermatology practice and dermatology residency teaching programs. Patients with dermatological diseases, few diseases arising due to COVID-19 and patients with immunosuppressive for chronic dermatological conditions were affected. In the midst of this pandemic, all dermatologist should learn and contribute to the mankind with precaution at all level either in healthcare or society.
\end{abstract}

C orona virus disease-2019 (COVID-19), which originated in Wuhan, China in late 2019, was declared by WHO as a pandemic on 11th March 2020. The disease has created havoc throughout the world. All sectors in the society were affected, especially the healthcare sector. Many of the healthcare personnel, doctors and nurses, who had been the frontline warriors against COVID-19 got infected and had lost their lives in this battle.

In Nepal, as of this day there are around 7 lakhs infected and nearly ten thousand deaths due to COVID-19. ${ }^{1}$ The frontline health workers including a dermatologist also played a crucial role on COVID-19. The impact of pandemic had a foothold even on dermatology practice. Dermatologists were also enrolled in COVID duties. Dermatology residency teaching programs completely turned into online learning sessions. Learning activities in outpatients and even procedures were hampered. The seminars and conference were postponed, cancelled or changed to virtual format. The scheduled exams were postponed. The research works also were balked. The impact was not only physical but psychological too. Dermatologists were deferring surgical practice, switching on to tele-dermatology, and social media consultation through Viber, WhatsApp, Facebook etc. ${ }^{2}$ Patients were conveyed during online consultation with pitfalls of non-physical interactions. The common consultations were for fungal infection,

Funding: No

Conflict of Interest: No

Address of Correspondence

Dr. Deeptara Pathak Thapa

ORCID ID: 0000-0002-1602-415X

Department of Dermatology, Nepal Medical College

Kathmandu, Nepal

E-mail: drdeeptarapathak@yahoo.com bacterial infection, urticaria, dermatitis, pigmentary disorders acne to name a few but was difficult to manage few diseases like immunobullous diseases, chronic inflammatory diseases specially those on immunosuppressive drugs. ${ }^{3}$ At present, the scenario after the vaccination drive has been changed with regular consultation of patients with proper precaution with mask, face shield and sanitizing of hands after every consultation and social distancing. During this pandemic, few of the dermatoses had emerged as maskinduced acneiform lesions, miliaria, contact dermatitis to sanitizers and personal protective equipment (PPEs) etc. Health talks regarding awareness programs about the use of masks and sanitizers were also underpinned.

The spectrum of cutaneous manifestations of COVID-19 are urticarial, morbiliform, vesicular, vasoocclusive and pseudo-chilblains. ${ }^{4}$ Multisystem inflammatory syndromes which simulate Kawasaki disease were commonly seen in the pediatric population. ${ }^{5}$ There is scarcity of data regarding cutaneous manifestation of COVID-19 from Nepal, a case report of Erythema multiforme like lesion has been reported. ${ }^{6}$ As the COVID-19 pandemic picked up the threads, many of the cutaneous manifestations reported could be explained by the "Baader-Meinhof phenomenon" which

Date of Submission: $19^{\text {th }}$ June, 2021

Date of Acceptance: $30^{\text {th }}$ August, 2021

Date of Publication: $1^{\text {st }}$ October 2021

How to cite this article

Thapa DP, Paudel V. COVID-19 and Dermatologist: A scenario from Nepal. NJDVL 2021;19(2):1-2. https://doi.org/10.3126/ njdvl.v19i2.39365.

\section{(c) (i)}

Licensed under CC BY 4.0 International License which permits use, distribution and reproduction in any medium, provided the original work is properly cited. 
is a frequency illusion and regarded as cognitive bias in which, there is a tendency to notice more frequently after noticing for the first time leading to selection bias. COVID toes, which were reported from different parts of the world as a distinctive sign of COVID-19 disease but subsequently was found to be an "epiphenomenon".7

The COVID-19 has taught us many lessons, and still we are learning newer things. Treating physician still needs to take a precaution while attending patients.

\section{References}

1. Coronavirus Update (Live):651,380 cases and 9,320 deaths from COVID -19 Virus Pandemic. Worldometer. Archived from the original on 9th July 2020. Retrieved 9 July. https://www. worldometers.info/coronavirus/country/nepal/

2. Paudel V. The Increasing Scope of Teledermatology in Nepal. JNMA J Nepal Med Assoc. 2020 Dec;58(232):1100-2. https://doi.org/10.31729/ jnma.5318.

3. Marahatta S. The experience of mobile teledermatology during COVID-19 pandemic in Nepal: A feasible alternative even in the developing world. Our Dermatol Online. 2021;12(2):204-205 https://doi.org/10.7241/ourd.20212.29
Dermatology residency programs which were totally pretentious initially now are coming in track as learning sessions are more on online mode, they are having shift duties, having exams in semi-online mode, few online while few with precautions maintaining social distancing, sanitizing etc. In the midst of this pandemic, all dermatologist should learn and contribute to the mankind and should adhere to the key role of dermatologist pertaining to treat and research regarding COVID-19.
4. Tan SE, Tam YC, Oh CC. Skin manifestations of COVID-19: A worldwide review. JAAD Int. 2021 Mar; 2:119-133 https://doi.org/10.1016/j. jdin.2020.12.003

5. Naka F, Melnick L, Gorelik M, Morel KD. A dermatologic perspective on multisystem inflammatory syndrome in children. Clin Dermatol 2021; 39:163-8. https://doi.org/10.1016/j. clindermatol.2020.09.003 .

6. Mainali P, Thapa DP. Erythema multiforme like lesion: A COVID-19 manifestation? 2021;12(2):202-203. https://doi.org/10.7241/ ourd. 20212.28

7. Das A. COVID-19 and dermatology. Indian J Dermatol. 2021 July; 66:229-30. https://doi. org/10.4103/ijd.ijd_461_21 